\title{
Effects of Tillage and Crop Establishment Methods, Crop Residues, and Nitrogen Levels on Wheat Productivity, Energy-savings and Greenhouse Gas Emission under Rice -Wheat Cropping System
}

\author{
G. Sah ${ }^{\text {1* }}$, S.C. Shah ${ }^{2}$, S.K. Sah ${ }^{3}$, R.B. Thapa ${ }^{2}$, A. McDonald ${ }^{4}$, H.S. Sidhu ${ }^{5}$, R.K. Gupta ${ }^{5}$, \\ B.P. Tripathi ${ }^{6}$, S.E. Justice ${ }^{4}$ \\ ${ }^{1}$ Nepal Agricultural Research Council, Kathmandu, Nepal \\ ${ }^{2}$ Institute of Agriculture and Animal Science, Tribhuvan University, Chitwan, Nepal \\ ${ }^{3}$ University of Agriculture and Forestry, Chitwan, Nepal \\ ${ }^{4}$ CIMMYT, South Asian Regional Office, Nepal \\ ${ }^{5}$ Borlaug Institute for South Asia, India \\ ${ }^{6}$ International Rice Research Institute-Nepal Office \\ e-mail: sahganesh35@yahoo.com
}

\begin{abstract}
Field experiments were conducted to evaluate conventional tillage (CT), permanent raised bed (PRB), and zero tillage (ZT) with residue retention and removal at three nitrogen levels $\left(0,100\right.$, and $\left.120 \mathrm{~kg} \mathrm{~N} \mathrm{ha}^{-1}\right)$ on wheat productivity, energy input and energy output, energy use efficiency, specific energy, and $\mathrm{CO}_{2}$ emission from 2010 to 2012 under rice-wheat system at Pheta V.D.C, Bara, Nepal. The experiments were carried out in strip split plot designs with three replications. Zero tillage wheat produced significantly higher grain yield $\left(2616.5 \mathrm{~kg} \mathrm{ha}^{-1}\right)$, saved $10.4 \%$ energy input, increased energy output (12.4\%), enhancing energy use efficiency by $25.2 \%$ and reducing specific energy by $23.6 \%$, as compared to conventional tillage. Diesel consumption on crop establishment and irrigations were the lowest for ZT (48.6 liter ha' $\left.{ }^{-1}\right)$ and the highest for CT $\left(86.3\right.$ liter ha $\left.^{-1}\right)$. PRB consumed the lowest quantity of diesel on two irrigations (34.6 liter ha $\mathrm{a}^{-1}$ ) with higher energy use efficiency (3.4\%) and lower specific energy $\left(8.76 \mathrm{MJ} \mathrm{kg}^{-1}\right)$ over CT. The $\mathrm{CO}_{2}$ emission from CT was the highest $\left(224.32 \mathrm{~kg} \mathrm{ha}^{-1}\right)$ over ZT (126.4 $\mathrm{kg} \mathrm{ha}$ $\left.{ }^{1}\right)$ and PRB $\left(146.11 \mathrm{~kg} \mathrm{ha}^{-1}\right)$. Residue retention increased $4 \%$ grain yield over residue removal. Without nitrogen application, energy output was the lowest (34192 $\left.\mathrm{MJ} \mathrm{ha}^{-1}\right)$ with the highest specific energy $\left(12.6 \mathrm{MJ} \mathrm{kg}^{-1}\right)$. Thus, zero-till wheat with $40-\mathrm{cm}$ residue retention and $100 \mathrm{~kg} \mathrm{~N} \mathrm{ha}^{-1}$ application was suggested for mass scale adoption in the Tarai region of Nepal.
\end{abstract}

Key words: $\mathrm{CO}_{2}$ emission, climate change, energy input/output, fossil fuel, specific energy

\section{Introduction}

Wheat (Triticum aestivum) is a major crop supporting food security in South Asia. Around $42 \%$ of the wheat in this region is grown following rice (Oryza sativa) covering 13.5 million hectares of land. In Nepal, wheat is the third important cereal after rice and maize. It occupies $20 \%$ of total cereal area and contributes about $19 \%$ of the total cereal production in the country. The area under wheat is 0.75 million ha with the productivity of $2290 \mathrm{~kg} \mathrm{ha}^{-1}$ (MoAD, 2012/13) following rice occupying 0.56 million ha (Tripathi et al. 2002).

The rice-wheat system supports more than 450 million people and contributes more than $80 \%$ of the total cereal production in Bangladesh, India, Nepal, and Pakistan (Ladha et al. 2003). The system produces staple food for more than one billion people or about $15 \%$ of the world's population. Where, resource 
conserving technologies, grown on 4.0 million ha of land in the Indo-Gangetic Plains (Ladha et al. 2003), increase input use efficiency, cuts costs, provides various environmental benefits, and ultimately improves farmers' livelihoods and helps to reduce poverty (Hobbs \& Gupta 2003).

Rice and wheat are the fertility exhaustive crops and need more water, labor, time, heavy farm machineries, costs, and non-renewable energy for their successful cultivation (Jha et al. 2011). Conventional tillage for wheat establishment requires repeated soil tilling, 6-8 times (Hobbs \& Gupta 2003) and planking (5 times) causing delayed planting, soil health, and higher production cost. Late wheat planting causes $30-50 \mathrm{~kg}$ day $^{-1}$ ha $^{-1}$ yield reduction which could not be reversed with better crop management and application of inputs. However, wheat sowing can be accomplished efficiently with the use of conservation-based machineries, i.e. zero-till seed drill, rotary seed drill, and bed planter etc. to save time, fossil fuel, cost, and energy (Grace et al. 2003, Jha et al. 2007). Zero-till wheat uses reduced water requirements by about 10 $\mathrm{cm}$ or approximately one million liter $\mathrm{ha}^{-1}$ (Hobbs \& Gupta 2003). Also, bed planted wheat saves $35 \%$ irrigation water as compared to flat-planted wheat (Sayre \& Ramos 1997, Sayre 2000, Malik et al. 2002).

Like other crops, wheat requires application of both animate (bullock, human power) and inanimate (tractors, tillers, pump-sets, seed drill etc.) forms of energy at different stages. Zero tillage has a direct mitigation effect as it converts the GHG, like $\mathrm{CO}_{2}$ into $\mathrm{O}_{2}$ and carbon in the atmosphere, and enriches soil organic matter. Adopting zero tillage on even one million ha of rice-wheat area, a reduction in diesel use of 60 million liter and $\mathrm{CO}_{2}$ emission of more than $156,000 \mathrm{Mg} \mathrm{yr}^{-1}$ would be obtained, using a conversion factor of $2.6 \mathrm{~kg} \mathrm{CO}_{2}$ produced per liter of diesel burned (Hobbs \& Gupta 2003).

Climate change can increase potential soil erosion rates, which lower agricultural productivity by 10 to $20 \%$, or more in extreme cases, (Jorge et al. 2011). By growing nitrogen fertilizer use and increased livestock production, methane and nitrous oxide emissions are projected to further increase from 35 to $60 \%$ by 2030 (Varshneya 2009, Venkateswaralu \& Shanker 2009). During the last 150 years, the rate of increase of temperature was $0.045^{\circ} \mathrm{C}$, for last 100 years
$0.074{ }^{\circ} \mathrm{C}$, for the last 50 years $0.128{ }^{\circ} \mathrm{C}$, and for the last 25 years $0.177^{\circ} \mathrm{C}$ per decade, indicating that the recent rate of increase of temperature was the highest compared to that of previous years (Manning 2007). Increase in temperature in Nepalese context is 0.06 ${ }^{0} \mathrm{C} \mathrm{yr}^{-1}, 0.04{ }^{0} \mathrm{C}$ in the Tarai and $0.08{ }^{0} \mathrm{C} \mathrm{yr}^{-1}$ in high mountain. The main source of $\mathrm{CO}_{2}$ emission to the atmosphere in the rice-wheat system is through tillage. Two onsite tillage sources exist: the biological decomposition of soil organic matter and the production of $\mathrm{CO}_{2}$ as a byproduct of machinery fuel usage. During tillage soil aggregates are broken, surface area exposure of organic material is increased thus increasing oxygen supply and promoting the decomposition of organic matter. Assuming that 150 liter $\mathrm{ha}^{-1} \mathrm{yr}^{-1}$ of fuel are used for tractor usage and irrigation pumping in conventional systems, this would amount to nearly $400 \mathrm{~kg}$ of $\mathrm{CO}_{2}$ being emitted (Grace et al. 2003). Therefore, diesel is a greatly underestimated source of GHGs. Thus, the experiments were conducted with the objectives to evaluate eco-friendly and energy-effective wheat establishment options for long-term production sustainability.

\section{Methodology}

The experiments were carried out on farmer's field at Pheta VDC, Bara district, Nepal for consecutive two years (2010/11 and 2011/12). The soil of the experimental field was silty loam and slightly acidic in reaction ( $\mathrm{pH} 5.7)$, high in organic matter $(4.98 \%)$, high in total $\mathrm{N}(0.241 \%)$, very high in $\mathrm{P}_{2} \mathrm{O}_{5}(379 \mathrm{~kg}$ $\left.\mathrm{ha}^{-1}\right)$, and medium in exchangeable $\mathrm{K}_{2} \mathrm{O}\left(118 \mathrm{~kg} \mathrm{ha}^{-1}\right)$ contents. The experiments consisted of three factors: (a) tillage and crop establishment methods, (b) residue management, and (c) nitrogen levels for both the crops under rice-wheat system and were conducted in stripsplit plot design with three replications. The size of each plot was $37.8 \mathrm{~m}^{2}$ (7 $\left.\mathrm{m} \times 5.4 \mathrm{~m}\right)$, as the seeding widths of the zero-till (ZT) drill and the furrow irrigated raised bed (FIRB) drill were $1.8 \mathrm{~m}$ and 1.35 $\mathrm{m}$, respectively. The tillage and crop establishment methods comprised of (i) conventional tillage (CT): plots were ploughed twice (double passes each time) using tractor-drawn cultivator followed by wooden planking. Seed and basal fertilizers were manually broadcast on the tilled soil surface followed by shallow seed and soil manipulation with the cultivator and light planking; (ii) permanent raised bed (PRB): seeds were 
drilled, $5 \mathrm{~cm}$ deep, over rice harvested bed tops, in two rows, after superficial reshaping using (FIRB) drill; and (iii) zero tillage (ZT): seeds were drilled, $5 \mathrm{~cm}$ deep, on untilled rice harvested plots using inclined plate zero-till seed drill. The residue management consisted of (i) residue retention $\left(R_{R}\right)$ : $40 \mathrm{~cm}$ stubbles of preceding crop were left at harvest and (ii) residue removal $\left(\mathrm{R}_{\mathrm{O}}\right)$ : preceding crop was harvested from ground level leaving about $5 \mathrm{~cm}$ stubbles. The nitrogen levels were: (i) zero nitrogen $\left(\mathrm{N}_{\mathrm{O}}\right): 0 \mathrm{~kg} \mathrm{~N} \mathrm{ha}{ }^{-1}$; (ii) Farmers' nitrogen $\left(\mathrm{N}_{100}\right): 100 \mathrm{~kg}$ $\mathrm{N} \mathrm{ha}{ }^{-1}$; and (iii) Abundant nitrogen $\left(\mathrm{N}_{120}\right): 120 \mathrm{~kg} \mathrm{~N}$ $\mathrm{ha}^{-1}$. Of the nitrogen levels, half $\mathrm{N}$ was applied as basal at sowing time and the remaining $\mathrm{N}$ in two equal split dozes applied on crown root initiation stage (23 DAS) and maximum tillering stage (54 DAS). Phosphorus $\left(\mathrm{P}_{2} \mathrm{O}_{5}\right)$ and potassium $\left(\mathrm{K}_{2} \mathrm{O}\right)$ were applied @ $60 \mathrm{~kg} \mathrm{ha}$ ${ }^{1}$ and $40 \mathrm{~kg} \mathrm{ha}^{-1}$, respectively, as basal at sowing. The sources of fertilizers were urea, triple super phosphate, and muriate of potash. Wheat variety 'Gautam' with seed @ $120 \mathrm{~kg} \mathrm{ha}^{-1}$ for CT and ZT and $80 \mathrm{~kg} \mathrm{ha}^{-1}$ for PRB, was sown on Dec. 10, 2010 and Dec. 11, 2011. Pre-sowing irrigation was applied to ensure optimum soil moisture a week before sowing to all the plots. Two irrigations were applied on 22 and 53 days after sowing (DAS) during the crop cycles. Irrigation water was lifted from a shallow tube-well and was conveyed to the individual plots through a $10-\mathrm{cm}$ diameter polyvinyl chloride (PVC) pipe, using a diesel pump-set. The depth of irrigation water applied was $5 \mathrm{~cm}$ for CT and ZT and $5 \mathrm{~cm}$ below from bed-top in the furrows for PRB. For weed control, a mixture of Isoproturon + 2, 4-D@ $900 \mathrm{~g} \mathrm{ha}^{-1}$ each in 700 liters water was sprayed using a knap-sack sprayer, at 35 DAS. The rainfalls at the site during $1^{\text {st }}$ and $2^{\text {nd }}$ year were 33.6 $\mathrm{mm}$ and $43.5 \mathrm{~mm}$ in 3 and 6 spells, respectively. Human labor used for all operations and management practice, amounts of all inputs and outputs, pump set used for irrigation, and machinery usage were recorded for each plot. Grain and straw yields were determined by manually harvesting five random samples $\left(2 \mathrm{~m}^{2}\right.$ each for CT and ZT and $2.7 \mathrm{~m}^{2}$ for PRB) from each plot, leaving border rows, at physiological maturity. The samples were weighed, threshed, and cleaned. The cleaned grains were weighed and their moisture contents were observed with the help of a digital moisture meter (Wile 35). The grain yields $\left(\mathrm{kg} \mathrm{ha}^{-1}\right)$ were computed at $12 \%$ moisture content, using equation (I) and (II) and the data were analyzed using Genstat 5 (Sec. edition):
Observed grain yield $\left(\mathrm{kg} \mathrm{ha}^{-1}\right)=$ Observed grain yield $\left(\mathrm{kg} \mathrm{m}^{-2}\right) \times 10,000 \longrightarrow$ (I)

Grain yield at $12 \%$ moisture content $\left(\mathrm{kg} \mathrm{ha}^{-1}\right)=$ Observed grain yield $\left(\mathrm{kg} \mathrm{ha}^{-1}\right) \mathrm{X}(100$ - observed moisture content, \%)/(100-12,\%)

Straw yields were calculated on sun- dry weight basis using equation (III):

Observed straw yield $\left(\mathrm{kg} \mathrm{ha}^{-1}\right)=$ Observed straw yield $\left(\mathrm{kg} \mathrm{m}^{-2}\right) \times 10,000-$ (III)

The variable input energy sources included were human labor, machinery (tractor, cultivator, seed drills, pump-set, and thresher), fossil fuel and the inputs of production (seed, fertilizers, and chemicals). The energy input, energy output, and energy use efficiency were calculated using energy coefficients (Table 5) given by Mittal et al. 1985 and procedures given by Devasenapathy et al. 2009. Following assumptions were made for input energy calculations:

CT land preparation time- $8.25\left(h r h a^{-1}\right)$

Tractor plowing (double pass) with cultivator- $1^{\text {st }}$ plowing- $3 ; 2^{\text {nd }}$ plowing- 2.5 ; planking- 1 ; seed + soil manipulation-1; light planking- $0.75\left(\mathrm{hr} \mathrm{ha}^{-1}\right)$

PRB planting time- $6.17\left(\mathrm{hr} \mathrm{ha^{-1 }}\right)$

Reshaping with tractor + bed former- 2.68; seed drilling time-3.49 $\left(\mathrm{hr} \mathrm{ha}^{-1}\right)$

\section{ZT planting time- $2.61\left(\mathrm{hr} \mathrm{ha}^{-1}\right)$}

The energy input was calculated using equation (IV) used by Devasenapathy et al. (2009):

Energy input $\left(\mathrm{MJ} \mathrm{ha}^{-1}\right)=$ Tractor, cultivator, seed drill, and/or pump set weight $(\mathrm{kg}) \mathrm{X}$ energy coefficient (MJ unit $\left.{ }^{-1}\right) X$ operation (hr)/life span (hr)___(IV)

Where, tractor, cultivator, seed drill, and pump set weight were $2500,400,400$, and $50 \mathrm{~kg}$ with their life span of 12000, 6000, 2400, and $10500 \mathrm{hr}$, respectively. Diesel consumption for tractor and pump set were 3.5 and 0.8 (liter $\mathrm{hr}^{-1}$ ). Pump set operation duration (in two irrigations) for CT, PRB, and ZT were 71.75, 43.25, and $49.35 \mathrm{hr}$ ha${ }^{1}$, respectively. Irrigation water applications for CT, PRB, and ZT were 1145,678 , and $777 \mathrm{~m}^{3} \mathrm{ha}^{-1}$, respectively. Harvesting charge@180 man-hr ha ${ }^{-1}$.Threshing and cleaning charge @ 10\% of threshed grains. 
Specific energy was calculated using equation $(\mathrm{V})$ used by Laik et al. (2014):

Specific energy $\left(\mathrm{MJ} \mathrm{kg}^{-1}\right)=$ Energy input $\left(\mathrm{MJ} \mathrm{ha}^{-1}\right) /$ Economic yield $\left(\mathrm{kg} \mathrm{ha}^{-1}\right) \longrightarrow(\mathrm{V})$

\section{Results and Discussion}

\section{Grain yield}

The grain yields, over the years, were significantly influenced by the tillage and crop establishment (TCE) methods. The highest grain yield $\left(2616.5 \mathrm{~kg} \mathrm{ha}^{-1}\right)$ was recorded from zero tillage (ZT) followed by CT $\left(2231.5 \mathrm{~kg} \mathrm{ha}^{-1}\right)$ and the lowest by PRB (2163 kg ha$\left.{ }^{1}\right)$. Zero tillage produced significantly higher grain yield than CT and PRB by $17.3 \%$ and $21.0 \%$, respectively, while, $\mathrm{CT}$ and $\mathrm{PRB}$ were at par (Table 1). The higher grain yield from $\mathrm{ZT}$ is attributed to minimum soil disturbance, prolonged soil moisture conservation, uniform seed distribution, proper seeding depth, and higher nutrient efficiency. The results were in accordance with the findings of Hobbs et al. (1997), Gupta et al. (2000), and Gupta et al. (2003). Melha et al. (2000) also reported $6 \%$ higher yield in timely sown zero tillage wheat than the timely sown conventionally tilled wheat crop. Residue retention produced slightly higher grain yield $(93 \mathrm{~kg}$ $\mathrm{ha}^{-1}$ ) than residue removal. Grain yields varied with increased nitrogen doze. Grain yield at $\mathrm{N}_{0}$ was $60 \%$ lower than farmers' $\mathrm{N}\left(100 \mathrm{~kg} \mathrm{ha}^{-1}\right)$. The higher grain yields from increased $\mathrm{N}$ doze attributed to more plant chlorophyll, plant vigor, more tillers, more leaf area index, more grains per spike and specific grain weight. The results were similar to the findings of other researchers (Ram 2000, Balasubramanian et al. 2000).

\section{Straw yield}

The tillage and crop establishment methods did not show significant effect on straw yields despite difference in grain yield. However, zero tillage produced higher straw yields by $7.7 \%$ and $12.8 \%$ than CT and PRB, respectively. Residue removal $\left(\mathrm{R}_{\mathrm{O}}\right)$ showed significantly higher straw yield by $29.2 \%$ compared to residue retention $\left(R_{R}\right)$, over the years. In $R_{R}, 40 \mathrm{~cm}$ residues were left in situ, while, in $R_{0}$ all the residues were collected increasing straw yields. The increased $\mathrm{N}$ applications significantly increased straw yields over the years (Table 1).

Table 1. Wheat yields, energy input/output, energy use efficiency, and specific energy as influenced by tillage methods, residue management, and nitrogen levels at Pheta, Bara, Nepal, 2010/11 and 2011/12

\begin{tabular}{|c|c|c|c|c|c|c|}
\hline \multirow[t]{2}{*}{ Treatments } & \multicolumn{2}{|c|}{ Yields $\left(\mathrm{kg} \mathrm{ha}^{-1}\right)$} & \multicolumn{4}{|c|}{ Energy } \\
\hline & Grain & Straw & $\begin{array}{c}\text { Input } \\
\left(\mathrm{MJ} \mathrm{ha}^{-1}\right)\end{array}$ & $\begin{array}{c}\text { Output } \\
\left(\mathrm{MJ} \mathrm{ha}^{-1}\right)\end{array}$ & $\begin{array}{c}\text { Use efficiency } \\
(\%)\end{array}$ & $\begin{array}{l}\text { Specific } \\
\left(\mathrm{MJ} \mathrm{kg}^{-1}\right) \\
\end{array}$ \\
\hline $\begin{array}{l}\text { Tillage methods: } \\
\text { Conventional tillage }(\mathrm{CT}) \\
\text { Permanent raised bed (PRB) } \\
\text { Zero-tillage }(\mathrm{ZT}) \\
\text { LSD }_{(0.05)} \\
\text { F-test }_{(0.05)}\end{array}$ & $\begin{array}{c}2231.5 \\
2163.0 \\
2616.5 \\
125.3 \\
* * \\
\end{array}$ & $\begin{array}{c}2728.5 \\
2606.0 \\
2939.0 \\
305.5 \\
\mathrm{NS} \\
\end{array}$ & $\begin{array}{l}22164.8 \\
18948.5 \\
19861.9 \\
- \\
- \\
\end{array}$ & $\begin{array}{c}66908 \\
64361 \\
75191 \\
4688.2 \\
* * \\
\end{array}$ & $\begin{array}{l}3.02 \\
3.40 \\
3.78 \\
- \\
- \\
\end{array}$ & $\begin{array}{l}9.93 \\
8.76 \\
7.59 \\
- \\
- \\
\end{array}$ \\
\hline $\begin{array}{l}\text { Residue management: } \\
\text { Residue retention }\left(\mathrm{R}_{\mathrm{R}}\right) \\
\text { Residue removal }\left(\mathrm{R}_{\mathrm{O}}\right) \\
\mathrm{LSD}_{(0.05)} \\
\text { F-test }_{(0.05)}\end{array}$ & $\begin{array}{c}2384.5 \\
2291.5 \\
102.3 \\
\mathrm{NS}\end{array}$ & $\begin{array}{c}2406.0 \\
3109.0 \\
249.5 \\
* *\end{array}$ & $\begin{array}{c}24785.7 \\
15864.5 \\
- \\
- \\
\end{array}$ & $\begin{array}{c}65096 \\
72544 \\
3827.9 \\
* * \\
\end{array}$ & $\begin{array}{c}2.63 \\
4.57 \\
- \\
- \\
\end{array}$ & $\begin{array}{c}10.39 \\
6.92 \\
- \\
- \\
\end{array}$ \\
\hline $\begin{array}{l}\text { Nitrogen level: } \\
\text { Control N doze }\left(\mathrm{N}_{0}\right) \\
\text { Farmer's } \mathrm{N} \text { doze }\left(\mathrm{N}_{100}\right) \\
\text { Abundant } \mathrm{N} \text { doze }\left(\mathrm{N}_{120}\right) \\
\text { LSD }_{(0.05)} \\
\text { F-test }(0.05) \\
\text { C.V. }(\%)\end{array}$ & $\begin{array}{c}1122.5 \\
2854.0 \\
3034.0 \\
125.3 \\
* * \\
7.9\end{array}$ & $\begin{array}{c}1415.5 \\
3347.5 \\
3510.0 \\
305.5 \\
* * \\
16.4\end{array}$ & $\begin{array}{c}14095.9 \\
22701.1 \\
24178.3 \\
- \\
- \\
-\end{array}$ & $\begin{array}{c}34192 \\
83795 \\
88473 \\
4688.2 \\
* * \\
10.1\end{array}$ & $\begin{array}{c}2.42 \\
3.69 \\
3.66 \\
- \\
- \\
-\end{array}$ & $\begin{array}{c}12.56 \\
7.95 \\
7.97 \\
- \\
- \\
-\end{array}$ \\
\hline
\end{tabular}

$*=$ significant at $5 \%$ level of significance, $* *=$ significant at $1 \%$ level of significance, $\mathrm{NS}=$ not significant 


\section{Energy-savings}

The comparison of energy use pattern (Table 1) from different crop establishment methods of wheat revealed that the highest input energy consumption was (22164.8 $\mathrm{MJ} \mathrm{ha}^{-1}$ ) for CT and the lowest (18948.5 MJ ha $^{-1}$ ) was for PRB which was closely followed by ZT (19861.9 $\mathrm{MJ} \mathrm{ha}^{-1}$ ). The results were similar to the findings of other researchers (Jain et al. 2007, Jha et al. 2011, Singh et al. 2011). The higher energy consumption under CT than ZT, attributed to more tillage operation. Residue retention proved $56 \%$ higher energy consuming than residue removal. The reason for higher energy use for $R_{R}$ attributed to $40-\mathrm{cm}$ residues left in situ. Compared to zero $\mathrm{N}$, the energy inputs were higher by $71 \%$ and $61 \%$ for $120 \mathrm{~kg} \mathrm{~N} \mathrm{ha-}$ ${ }^{1}$ and $100 \mathrm{~kg} \mathrm{~N} \mathrm{ha}^{-1}$, respectively. The energy outputs for the TCE methods varied significantly. However, the highest energy output (75191 $\left.\mathrm{MJ} \mathrm{ha}^{-1}\right)$ was obtained from ZT followed by CT (66908 $\left.\mathrm{MJ} \mathrm{ha}^{-1}\right)$ and the lowest from PRB (64361 MJ ha-1). Residue removal proved more energy output (7448 $\mathrm{MJ} \mathrm{ha}^{-1}$ ) than residue retention as residues added more to energy output. The abundant $\mathrm{N}\left(120 \mathrm{~kg} \mathrm{ha}^{-1}\right)$ produced the highest energy output (88473 $\left.\mathrm{MJ} \mathrm{ha}^{-1}\right)$ followed by farmers' $\mathrm{N}$ (100 $\mathrm{kg} \mathrm{ha}^{-1}$ ) of $83795 \mathrm{MJ} \mathrm{ha}^{-1}$ and the lowest (34192 MJ $\mathrm{ha}^{-1}$ ) from zero $\mathrm{N}$ application. The energy use efficiency was 3.78, 3.4 and $3.02 \%$ for ZT, PRB, and $\mathrm{CT}$, respectively. The higher energy use efficiency under ZT was mainly attributed to higher energy production with the use of relatively lesser energy utilization. The results were similar to the findings of several researchers (Jha et al. 2011, Sharma et al. 2008, Singh et al. 2011). Abundant N and farmers' N showed similar efficiencies. To produce a $\mathrm{kg}$ of wheat grain, CT, PRB, and ZT consumed 9.93, 8.76, and 7.59 MJ energy input, respectively. The results indicated that wheat productivity for $\mathrm{CT}<\mathrm{PRB}<\mathrm{ZT}$ per unit energy consumed. Residue retention utilized 10.39 MJ for a $\mathrm{kg}$ of wheat grain production when compared to 6.92 MJ for residue removal. The maximum energy (12.56 MJ) was utilized to produce a $\mathrm{kg}$ of wheat grain without $\mathrm{N}$ application, while, it was minimum $(7.95 \mathrm{MJ})$ by farmers' $\mathrm{N}$ and abundant $\mathrm{N}$ (7.97 MJ). Application of farmers' $\mathrm{N}$ was more beneficial.

\section{Operation-wise energy consumption}

With $100 \mathrm{~kg} \mathrm{~N} \mathrm{ha}^{-1}$ and residue removal, CT consumed the highest energy input (19642.5 $\mathrm{MJ} \mathrm{ha}^{-1}$ ) followed by ZT (18314.4 $\left.\mathrm{MJ} \mathrm{ha}^{-1}\right)$ and the lowest from permanent raised bed (16866.5 $\left.\mathrm{MJ} \mathrm{ha}^{-1}\right)$. The maximum energy utilization was through fertilizers application in all the TCE methods (Table 2). Conventionally grown wheat consumed energy on irrigation $(24.3 \%)$, threshing and cleaning (18\%), seeding $(9.5 \%)$, tillage and crop establishment $(9.1$ $\%)$, harvesting $(1.8 \%)$, and the least $(1.6 \%)$ on chemical application, while, PRB wheat consumed energy on threshing and cleaning $(22.1 \%)$, irrigation (17\%), TCE (8.2\%), seeding (7.2\%), harvesting (2.1 $\%)$, and the least $(1.8 \%)$ on chemical application. Zero-till wheat utilized energy on threshing and cleaning (27\%), irrigation (17.9\%), seeding (10\%), TCE (3.2\%), harvesting (1.9\%), and the least (1.7 $\%$ ) on chemical application. Thus, the minimum TCE cost was associated with ZT as seed sowing was accomplished in one tractor-pass. About one-fourth of the total energy consumption was spent on irrigation applications in CT, while, they were 17.9 and $17 \%$ in $\mathrm{ZT}$ and PRB, respectively, as more water was required for CT than others.

Table 2. Operation-wise energy consumption in wheat cultivation under different tillage and crop establishment methods at Pheta, Bara, Nepal, 2010/11-2011/12

\begin{tabular}{|c|c|c|c|c|c|c|}
\hline \multirow[t]{2}{*}{ Particulars of operation } & & & \multicolumn{4}{|c|}{ Total energy used ( $\left.\mathrm{MJ} \mathrm{ha}^{-1}\right)$} \\
\hline & $\begin{array}{c}\text { Conventional } \\
\text { tillage }\end{array}$ & $\begin{array}{l}\text { Percent of } \\
\text { total energy }\end{array}$ & $\begin{array}{l}\text { Permanent } \\
\text { Raised bed }\end{array}$ & $\begin{array}{l}\text { Percent of } \\
\text { total energy }\end{array}$ & $\begin{array}{l}\text { Zero } \\
\text { tillage }\end{array}$ & $\begin{array}{l}\text { Percent } \\
\text { of total } \\
\text { energy }\end{array}$ \\
\hline Tillage and crop establishment & 1780.8 & 9.1 & 1375.9 & 8.2 & 582.0 & 3.2 \\
\hline Fertilization & 7017.5 & 35.7 & 7017.5 & 41.6 & 7017.5 & 38.3 \\
\hline Seed sowing & 1871.0 & 9.5 & 1216.0 & 7.2 & 1824.0 & 10.0 \\
\hline Herbicide application & 310.0 & 1.6 & 310.0 & 1.8 & 310.0 & 1.7 \\
\hline Irrigation & 4775.0 & 24.3 & 2864.9 & 17.0 & 3272.7 & 17.9 \\
\hline Harvesting & 352.8 & 1.8 & 352.8 & 2.1 & 352.8 & 1.9 \\
\hline Threshing and cleaning & 3535.4 & 18.0 & 3729.4 & 22.1 & 4955.4 & 27.0 \\
\hline Total & 19642.5 & 100 & 16866.5 & 100 & 18314.4 & 100 \\
\hline
\end{tabular}




\section{Energy input and energy output}

The energy input (Table 3a) and energy output (Table $3 b)$ data revealed that conventional tillage (CT) in association with residue retention and $120 \mathrm{~kg} \mathrm{~N} \mathrm{ha}^{-1}$ consumed the maximum energy (30540 $\mathrm{MJ} \mathrm{ha}^{-1}$ ), while, it was minimum (8675.6 $\mathrm{MJ} \mathrm{ha}^{-1}$ ) for zero tillage combined with $\mathrm{N}_{0}$ and without residues $\left(\mathrm{R}_{\mathrm{O}}\right)$. Obviously, ZT had produced more energy outputs by $8284 \mathrm{MJ} \mathrm{ha}^{-1}$ and $10829 \mathrm{MJ} \mathrm{ha}^{-1}$ than CT and PRB, respectively. Likewise, residue removal proved better for energy output (7420 $\mathrm{MJ} \mathrm{ha}^{-1}$ ) than residue retention. Abundant $\mathrm{N}$ application produced significantly higher energy output (52810 $\mathrm{MJ} \mathrm{ha}^{-1}$ ) than control, but, was higher (5277 $\mathrm{MJ} \mathrm{ha}^{-1}$ ) than farmers' $N$. The results indicated that judicious fertilizer application was necessary for improving yields and reducing GHG emissions under high $\mathrm{CO}_{2}$ levels (Varshneya 2009).

\section{Greenhouse gas emission}

The $\mathrm{CO}_{2}$ emissions (Table 4) revealed that conventionally tilled (CT) wheat emitted the highest amount of $\mathrm{CO}_{2}\left(224 \mathrm{~kg} \mathrm{ha}^{-1}\right)$ followed by PRB (146 $\left.\mathrm{kg} \mathrm{ha}^{-1}\right)$ and the lowest from ZT (126 kg ha'). The highest $\mathrm{CO}_{2}$ emission through $\mathrm{CT}$ attributed to higher tractor usage on land preparation and more pumpingtime on irrigation. However, ZT and PBP wheat emitted lower $\mathrm{CO}_{2}$ to the atmosphere by $43.7 \%$ and $34.9 \%$, respectively, as compared to CT.

Table 3a. Energy input as influenced by tillage, residues, and nitrogen levels at Pheta, Bara, Nepal, 2010/11 and 2011/12

\begin{tabular}{|c|c|c|c|c|c|c|}
\hline \multirow[t]{3}{*}{ Particulars } & \multicolumn{6}{|c|}{ Energy input $\left(\mathrm{MJ} \mathrm{ha}^{-1}\right)$} \\
\hline & \multicolumn{3}{|c|}{ Residue retention } & \multicolumn{3}{|c|}{ Residue removal } \\
\hline & $\mathrm{N}_{0}$ & $\mathrm{~N}_{100}$ & $\mathrm{~N}_{120}$ & $\mathrm{~N}_{0}$ & $\mathrm{~N}_{100}$ & $\mathrm{~N}_{120}$ \\
\hline \multicolumn{7}{|c|}{ Conventional tillage } \\
\hline Tillage and crop establishment & 1780.76 & 1780.76 & 1780.76 & 1780.76 & 1780.76 & 1780.76 \\
\hline Fertilizers & 9745.02 & 15805.02 & 17017.02 & 957.52 & 7017.52 & 8229.52 \\
\hline Seed and sowing & 1871.00 & 1871.00 & 1871.00 & 1871.00 & 1871.00 & 1871.00 \\
\hline Herbicide/fertilizer application & 310.00 & 310.00 & 310.00 & 310.00 & 310.00 & 310.00 \\
\hline Irrigation (two) application & 4775.03 & 4775.03 & 4775.03 & 4775.03 & 4775.03 & 4775.03 \\
\hline Harvesting & 352.80 & 352.80 & 352.80 & 352.80 & 352.80 & 352.80 \\
\hline Threshing and cleaning & 1654.48 & 4198.32 & 4433.52 & 1755.18 & 3535.35 & 4103.05 \\
\hline Total energy input & 20489.09 & 29092.93 & 30540.13 & 11802.29 & 19642.46 & 21422.16 \\
\hline \multicolumn{7}{|c|}{ Permanent raised bed } \\
\hline Tillage and crop establishment & 1375.88 & 1375.88 & 1375.88 & 1375.88 & 1375.88 & 1375.88 \\
\hline Fertilizers & 9745.02 & 15805.02 & 17017.02 & 957.52 & 7017.52 & 8229.52 \\
\hline Seed and sowing & 1216.00 & 1216.00 & 1216.00 & 1216.00 & 1216.00 & 1216.00 \\
\hline Herbicide/fertilizer application & 310.00 & 310.00 & 310.00 & 310.00 & 310.00 & 310.00 \\
\hline Irrigation (two) application & 2864.92 & 2864.92 & 2864.92 & 2864.92 & 2864.92 & 2864.92 \\
\hline Harvesting & 352.80 & 352.80 & 352.80 & 352.80 & 352.80 & 352.80 \\
\hline Threshing and cleaning & 1833.82 & 3790.39 & 4014.57 & 1654.48 & 3729.39 & 4054.32 \\
\hline Total energy input & 17698.44 & 25715.01 & 27151.19 & 8731.6 & 16866.51 & 18403.44 \\
\hline \multicolumn{7}{|c|}{ Zero-tillage } \\
\hline Tillage and crop establishment & 582 & 582 & 582 & 582 & 582 & 582 \\
\hline Fertilizers & 9745.02 & 15805.02 & 17017.02 & 957.52 & 7017.52 & 8229.52 \\
\hline Seed and sowing & 1824.00 & 1824.00 & 1824.00 & 1824.00 & 1824.00 & 1824.00 \\
\hline Herbicide/fertilizer application & 310.00 & 310.00 & 310.00 & 310.00 & 310.00 & 310.00 \\
\hline Irrigation (two) application & 3272.67 & 3272.67 & 3272.67 & 3272.67 & 3272.67 & 3272.67 \\
\hline Harvesting & 352.80 & 352.80 & 352.80 & 352.80 & 352.80 & 352.80 \\
\hline Threshing and cleaning & 1625.08 & 4961.98 & 5006.08 & 1376.65 & 4955.37 & 5150.88 \\
\hline Total energy input & 17711.57 & 27108.47 & 28364.57 & 8675.64 & 18314.36 & 19721.87 \\
\hline
\end{tabular}

Note: Herbicide/fertilizer application $=310 \mathrm{MJ} \mathrm{ha}^{-1}$ same for all TCE; Harvesting $=352.8 \mathrm{MJ}^{-1} \mathrm{same}^{-}$for all TCE 
G. Sah et al/Effects of Tillage and Crop........

Table 3b. Energy output as influenced by tillage, residues, and nitrogen levels at Pheta, Bara, Nepal, 2010/ 11 and 2011/12

\begin{tabular}{c|c|c|c|c|c|c|c|c}
\hline \multirow{2}{*}{ Particular } & $\begin{array}{c}\text { Conventional } \\
\text { tillage }\end{array}$ & $\begin{array}{c}\text { Permanent } \\
\text { raised bed }\end{array}$ & $\begin{array}{c}\text { Zero } \\
\text { tillage }\end{array}$ & $\begin{array}{c}\text { Residue } \\
\text { retention } \\
\left(\mathrm{R}_{\mathrm{R}}\right)\end{array}$ & $\begin{array}{c}\text { Residue } \\
\text { removal } \\
\left(\mathrm{R}_{0}\right)\end{array}$ & $\begin{array}{c}\text { Control } \\
\mathrm{N} \text { dose } \\
\left(\mathrm{N}_{0}\right)\end{array}$ & $\begin{array}{c}\text { Farmers' } \\
\mathrm{N} \text { dose } \\
\left(\mathrm{N}_{100}\right)\end{array}$ & $\begin{array}{c}\text { Abundant } \\
\mathrm{N} \text { dose } \\
\left(\mathrm{N}_{120}\right)\end{array}$ \\
\hline Grain yield & 32803.05 & 31796.10 & 38462.50 & 35052.10 & 33685.00 & 17970.70 & 41953.80 & 44599.80 \\
Straw yield & 34106.25 & 32568.70 & 36731.20 & 30075.00 & 38862.50 & 17693.70 & 41843.70 \\
Total & 66909.30 & 64364.80 & 75193.70 & 65127.10 & 72547.50 & 35664.40 & 83197.50 & 88474.80 \\
\hline
\end{tabular}

Table 4. Carbon dioxide gas emission on diesel combustion in wheat cultivation at Pheta, Bara, Nepal, 2010/ 11-2011/12

\begin{tabular}{|c|c|c|c|c|c|}
\hline TCE methods & \multicolumn{3}{|c|}{ Diesel used (liter ha-1) } & $\mathrm{CO}_{2}$ ermission & $\mathrm{CO}_{2}$ change \\
\hline $\begin{array}{l}\text { Corve ntional tillage } \\
\text { Permanent raised bed } \\
\text { Zero tillage }\end{array}$ & $\begin{array}{c}\text { Tractor } \\
28.87 \\
21.59 \\
9.13\end{array}$ & $\begin{array}{c}\text { Pump-set } \\
57.4 \\
34.6 \\
39.48\end{array}$ & $\begin{array}{l}\text { Total } \\
86.27 \\
56.19 \\
48.61\end{array}$ & $\begin{array}{l}\left(\mathrm{kg} \mathrm{ha}^{-1}\right) \\
224.32 \\
146.11 \\
126.40\end{array}$ & $\begin{array}{c}\text { over CT }(\%) \\
\text { - } \\
34.9\left(\frac{1}{t}\right) \\
43.7(\mathrm{t})\end{array}$ \\
\hline
\end{tabular}

Table 5. Equivalents for direct and indirect sources of energy used in wheat production

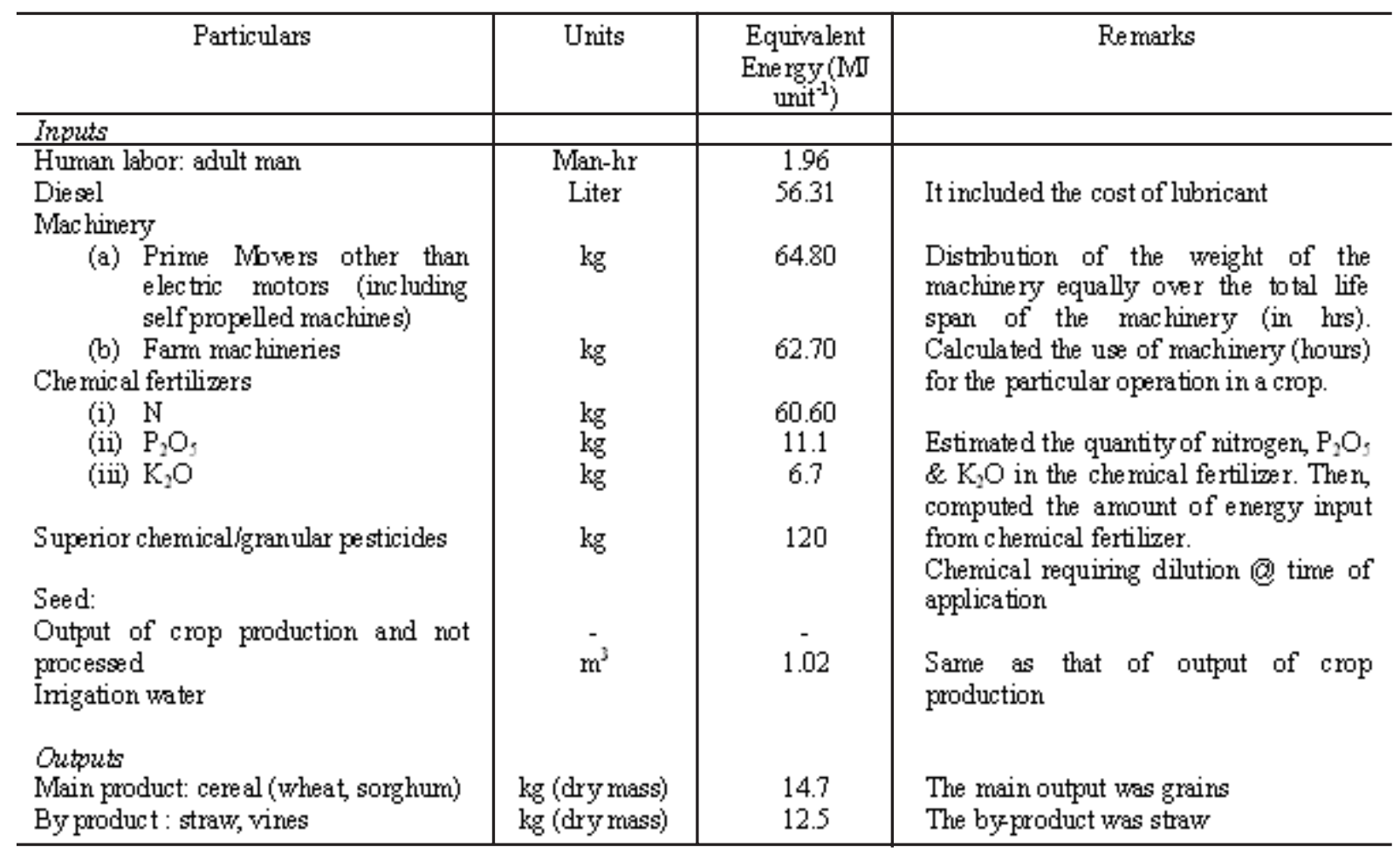

Sources: Mittal et al. (1985)

The higher crop productivity with lower energy uses and reduced $\mathrm{CO}_{2}$ gas emission is a prime need to meet the basic food demand of increasing population of Nepal, in climate change context. It was concluded that zero-till (ZT) wheat was the most beneficial for increased grain productivity $(17.3 \%)$ at lower energy consumption $(10.4 \%)$ and reduced specific energy
$(23.6 \%)$ with enhanced energy use efficiency $(25.2$ $\%)$, as compared to conventionally grown (CT) wheat. Zero-till wheat saved fossil fuel (diesel) burning (37.7 liter ha-1) with reduced $\mathrm{CO}_{2}$ emission $\left(98 \mathrm{~kg} \mathrm{ha}^{-1}\right)$ protecting environment from warming-up. Residue retention showed positive effects on grain productivity. Therefore, zero-till wheat combined with $40-\mathrm{cm}$ 
residue retention and $100 \mathrm{~kg} \mathrm{ha}^{-1} \mathrm{~N}$ application was suggested for mass-scale adoption in the Tarai region of Nepal to ensure long-term production sustainability.

\section{Acknowledgements}

The authors express their gratitude to the CIMMYTCSISA/Nepal Project for the financial support to conduct this study.

\section{References}

Balasubramanian, V., A.C. Morales, R.T. Cruz, T.M. Thiyagarajan, R. Nagrajan, M. Babu Abdulrachman and L.H. Hai. 2000. Adaptation of chlorophyll meter (SPAD) technology for real-time nitrogen management in rice: A review. Intl. Rice Res. Notes. 25 (1): 4-8.

Devasenapathy, P., G. Senthilkumar and P.M. Shanmugam, 2009. Energy management in crop production. Ind. $J$. Agron. 54 (1): 80-90.

Grace, P.R., L. Harrington, M.C. Jain and G.P. Robertson. 2003. Long-term sustainability of the tropical and subtropical rice-wheat system: An environmental perspective. In: Improving the productivity and sustainability of rice-wheat systems: Issues and impacts (eds. J.K. Ladha, E.H. James, J.M. Duxbury, R. K. Gupta, and R. J. Buresh). Amer. Soc. Agron. Spec. Publ. 65. ASA, CSSA, and SSSA, Madison, Wisconsin, USA. pp. 27-43.

Gupta, R.K., R.K. Naresh, P.R. Hobbs, Z. Jiaguo and J.K. Ladha. 2003. Sustainability of post-green revolution agriculture: The rice-wheat cropping systems of the Indo-Gangetic Plains and China. In: Improving the productivity and sustainability of rice-wheat systems: Issues and impacts (eds. J.K. Ladha, E.H. James, J.M. Duxbury, R. K. Gupta, and R. J. Buresh, ). Amer. Soc. Agron. Spec. Publ. 65. ASA, CSSA, and SSSA, Madison, Wisconsin, USA. pp.1-25.

Gupta, R.K., P.R. Hobbs and J.K. Ladha. 2000. From issue to action. In: Proceedings of the 6th meeting of the regional steering committee. Islamabad, Pakistan. $7-$ 8 Mar. 2000. Rice-Wheat Consortium for the IndoGangetic Plains, New Delhi, India. pp.1-7.

Hobbs, P.R. and R.K. Gupta. 2003. Resource-conserving technologies for wheat in the rice-wheat system. In: Improving the productivity and sustainability of ricewheat systems: Issues and impacts (eds. J.K. Ladha, E.H. James , J.M. Duxbury, R.K. Gupta, and R.J. Buresh). Amer. Soc. Agron. Spec. Publ. 65. ASA, CSSA, and SSSA, Madison, Wisconsin, USA. pp.149171.

Hobbs, P.R., G.S. Giri and P. Grace. 1997. Reduced and zero tillage options for the establishment of wheat after rice in South Asia. RWC-IGP Paper No. 2. Rice-Wheat
Consortium for the Indo-Gangetic Plains, New Delhi, India.

Jain, N., V. Jain, J.S. Mishra and M.L. Kewat. 2007. Effect of tillage packages and herbicide on energy and economics of wheat in transplanted rice-wheat system. Ind. J. Agric. Sci. 77 (3): 174-176.

Jha, A.K., R.S. Sharma and S.K. Vishwakarma. 2007. Development of resource conservation techniques for tillage and sowing management in rice-wheat cropping system under irrigated production system of Kymore Plateau and Satpura hillzone of Madhya Pradesh. JNKVV, Res. J. 41 (1):26-31.

Jha, A.K., M.L. Kewat, V.B. Upadhyay and S.K. Vishwakarma. 2011. Effect of tillage and sowing methods on productivity, economics and energetic of rice (Oryza sativa)-wheat (Triticum aestivum) cropping system. Ind. J. Agron. 56 (1): 35-50.

Jorge, A. Delgado, Petter M. Groffman, Mark A. Nearing, Tom Goddard, Don Reicosky, Rattan Lal, Newell R. Kitchen, Charles W. Rice, Dan Towery and Paul Salson. 2011. Conservation practices to mitigate and adapt to climate change. J. Soil Water Conservation. 66 (4): 118-129.

Ladha, J.K., H. Pathak, A.T. Padre, D. Dawe and R.K. Gupta. 2003. Productivity trends in intensive ricewheat cropping systems in Asia. In. Improving the productivity and sustainability of rice-wheat systems: issues and impacts (eds. J.K. Ladha, E.H. James, J.M. Duxbury, R. K. Gupta, and R. J. Buresh). Amer. Soc. Agron. Spec. Publ. No. 65. Madison, Wis. (USA): ASA, CSSA, and SSSA. pp. 45-76.

Laik, R., S. Sharma, M. Idris, A.K. Singh, S.S. Singh, B.P. Bhatt, Y. Saharawat, E. Humphreys and J.K. Ladha. 2014. Integration of conservation agriculture with best management practices for improving system performance of the rice-wheat rotation in the Eastern Indo-Gangetic Plains of India. J. Agric. Ecosys. Envi. 195: $68-82$.

Malik, R.K., A. Yadav, S. Singh, R.S. Malik, R.S. Balyan, R.S. Banga, P.K. Sardana, S. Jaipal, P.R. Hobbs, G. Gill, S. Singh, R.K. Gupta and R. Bellinder. 2002. Herbicide resistance management and evolution of zero tillage: A success story. Res. Bulle. Haryana Agricultural University, Hisar, India.

Manning, M. 2007. Climate change 2007: Observations and drivers of climate change. Presentation by Director of IPCC Working Group-I Support Unit, IPCC. pp. 41-73.

Melha, R.S., J.K. Verma, R.K. Gupta and P. R. Hobbs. 2000. Stagnation in the productivity of wheat in the IndoGangetic plains: Zero-till-seed-cum-fertilizer drill as an integrated solution. Rice-Wheat Consortium for the Indo-Gangetic Plains, New Delhi, India.

Mittal, V.K., J.P. Mittal and K.C. Dhawan. 1985. Research digest on energy requirements in agricultural sector. Co-ordinating Cell, AICP on energy requirements in 
G. Sah et al/Effects of Tillage and Crop

Agricultural Sector. Punjab Agricultural University, Ludhiana.

MoAD, 2012/13. Agricultural diary (2071 B.S.). Government of Nepal.

Ram, N. 2000. Long-term effects of fertilizers on ricewheat-cowpea productivity and soil properties in Mollisols. In. Long-term soil fertility experiments in rice-wheat cropping systems (eds. I.P. Abrol et al. eds.). Res. Series No. 6. Rice-Wheat Consortium, New Delhi, India. pp. 50-55.

Sayre, K.D. 2000. Effects of tillage, crop residue retention and nitrogen management on the performance of bedplanted, furrow-irrigated spring wheat in northwest Mexico. In: Proc. 15th Conf. Intl. Soil Till. Res. Org. (CD-ROM), Fort Worth, TX. 2-7 July, 2000.

Sayre, K.D. and O.H. Moreno Ramos. 1997. Applications of raised-bed planting systems to wheat. Wheat Program, Spec. Rep. 31. CIMMYT, Mexico.

Sharma, R.P., S.K. Pathak, K.R. Raman and N. Chattopadhyaya. 2008. Resource conservation in rice (Oryza sativa)-wheat (Triticum aestivum) for enhancing productivity, profitability, and soil health. In: Extended summaries, national symposium on new paradigm in agronomic research, 9 to 11 Nov. 2008, Navasari, Gujrat, India. Ind. Soc. Agron. pp. 236-237.

Singh, Veer, S. Ram, A. Bhatnagar and U. S. Savita. 2011. Effect of tillage methods on soil properties and productivity of quality protein maize (Zea mays)wheat (Triticum aestivum) system. Ind. J. Agron. 56 (2): 83-87.

Tripathi, J., D. Bhandari, S. Justice, N.K. Shakya, T.P. Kharel and R. Sishodia. 2002. Resource conservation technologies for wheat production in rice-wheat system. In: Proceedings of wheat research papers presented at the 25th National Winter Crops Workshop, Nepal.

Varshneya, M.C. 2009. Mitigation options for climate change. Ind. J. Agron. 54 (2): 231-236.

Venkateswarlu, B. and A. K. Shanker. 2009. Climate change and agriculture: Adaptation and mitigation strategies. Ind. J. Agron. 54 (2): 226-230. 
Nepal Journal of Science and Technology Vol. 15, No.2 (2014) 1-10 